\title{
Nutrient dynamics and constraints on the pre-laying exodus of High Arctic northern fulmars
}

\author{
M. L. Mallory ${ }^{1,2, *}$, M. R. Forbes ${ }^{2}$, C. D. Ankney ${ }^{3}$, R. T. Alisauskas ${ }^{4}$ \\ ${ }^{1}$ Canadian Wildlife Service, Box 1714, Iqaluit, Nunavut X0A 0H0, Canada \\ ${ }^{2}$ Department of Biology, Carleton University, Ottawa, Ontario K2S 5B6, Canada \\ ${ }^{3}$ Avian Energetics Lab, Bird Studies Canada, 115 Front Street, Port Rowan, Ontario N0E 1M0, Canada \\ ${ }^{4}$ Canadian Wildlife Service, 115 Perimeter Road, Saskatoon, Saskatchewan S7N 0X4, Canada
}

\begin{abstract}
Many aspects of the reproductive ecology of seabirds are linked to the phenology, quantity and accessibility of marine food supplies. In polar regions, annual sea ice constrains these aspects of marine productivity, and thus seabirds breeding at high latitudes may exhibit adaptations to accommodate these constraints. Like most petrels, northern fulmars Fulmarus glacialis undertake an exodus from their breeding colony just before egg-laying. To assess whether this exodus was related to energetic needs and stored nutrient reserves, we studied changes in body mass and composition of male and female fulmars breeding in the Canadian High Arctic, by comparing birds collected just before and just after the pre-laying exodus. Males gained body mass over this period, accumulating water, fat and protein, whereas females lost body mass, particularly protein and fat. Declines in female fat and protein approximated the amounts contributed to eggs, but water and mineral reserves in pre-exodus females appeared insufficient for egg production. We hypothesize that female fulmars leave the colony before egg-laying to meet mineral demands for egg production, possibly focusing on calcium-rich prey. In contrast, we hypothesize that males use a different strategy for resource acquisition and allocation, which seeks to maximize fat and protein accumulation to meet forthcoming incubation demands. Differences in typical marine environmental conditions at breeding colonies across the species' range probably account for observed behavioral variation in breeding schedules, and may also result in different nutrient dynamics.
\end{abstract}

KEY WORDS: Arctic $\cdot$ Body composition $\cdot$ Energetics $\cdot$ Procellariiformes $\cdot$ Reproduction

Resale or republication not permitted without written consent of the publisher

\section{INTRODUCTION}

Annual and long-term variation in the biophysical characteristics of the marine environment can have dramatic effects on marine food webs. This has been particularly well established in temperate and tropical waters in relation to climate change (Aebischer et al. 1990, Stenseth et al. 2004, Frederiksen et al. 2006), as well as in Arctic waters in relation to the timing of seaice breakup (Welch et al. 1992, Odate et al. 2002). As top predators in the oceans, fluctuations in marine productivity or specific food supplies can affect seabird behavior, reproductive success, or survival (e.g. Cairns 1987, Frederiksen et al. 2007). Thus, seabird ecology is tightly linked to the health and condition of marine ecosystems (reviewed in Boyd et al. 2006). This relationship should be pronounced in polar regions, because extreme winter climates and extensive sea-ice cover over feeding areas impose 3 significant energetic constraints on seabirds: (1) the need for birds to migrate from these regions for the winter, (2) shortened seasonal opportunities for reproduction and (3) spatially and temporally concentrated marine food resources (Raymont 1976). In the latter case, seabird reproduction in the Arctic is highly dependent on predictable or recurrent physical features of the marine environment, notably ice edges and polynyas (where marine food resources are more abundant and accessible; Stirling 1997), and the timing of ice breakup (Gaston et al. 2005). In the present study, we examine how 
aspects of the behavior and physiology of a broadly distributed seabird, the northern fulmar Fulmarus glacialis, are adapted to accommodate the constraints imposed by the High Arctic marine environment (Salomonsen 1965).

For many birds, body mass and composition (lipid, protein, mineral) of breeding individuals varies through the breeding cycle (Baldwin \& Kendeigh 1938, Ankney \& MacInnes 1978, Warham 1996). These changes are required to meet the energetic and nutritional demands of producing and incubating eggs, while still meeting self-maintenance needs (Drent \& Daan 1980). Lipid is the primary stored (endogenous) reserve of most birds (Griminger 1986, Cherel et al. 1994a,b), and is the main fuel used for incubation (Ricklefs et al. 1986), although protein is also metabolized (Blem 1990). The amount to which breeding birds rely on endogenous (capital) versus exogenous (income) sources of nutrients to meet their nutritional requirements of breeding varies markedly by species and breeding strategy, and influences patterns of change in body mass and composition (Meijer \& Drent 1999). Although body mass change and nutrient dynamics have been well studied for some birds, notably waterfowl (Alisauskas \& Ankney 1992) and penguins (e.g. Cherel et al. 1993, 1994a,b), this has received minimal attention in pelagic seabird research. These birds may chronically experience marginal food supplies (Lack 1968), because marine prey distributions may be ephemeral, patchy, difficult to find, or distant from the colony, often because suitable breeding sites are remote from suitable foraging areas (Warham 1990). Consequently, under such conditions, Grau (1984) suggested that meeting exogenous nutrient needs for egg production by pelagic seabirds may be critical for successful reproduction.

The Procellariiformes (hereafter petrels) are a group of mostly pelagic seabirds that share 2 reproductive characteristics: (1) all petrels lay a single, large, energyrich egg (Warham 1983) and (2) breeding female petrels (and most males) undertake an exodus from their colony just before their egg-laying date (Warham 1990, 1996). The prevailing hypothesis has been that, upon arrival at the colony, petrels require time to reestablish the pair bond, assess the condition of their nest site and their mate, and defend that site from conspecifics before egg-laying (Warham 1990). Following these activities, pairs may lack sufficient nutrient reserves to form an egg (female) or initiate incubation (male), and thus they depart the colony temporarily to meet this need (Warham 1990, 1996), at which time they feed heavily on fish, carrion, zooplankton, or other marine invertebrates.

Given these observations, and the ubiquitous acceptance of income breeding as the explanation for prelaying exodus by petrels, it is surprising that there have been few empirical attempts to verify this hypothesis (for any petrel; Lack 1968, Warham 1990, Whittow 2002). Marshall \& Serventy (1956) showed that female short-tailed shearwaters Puffinus tenuirostris had relatively small fat reserves at egg-laying, while male fat reserves were large (hence female nutrients were likely shunted towards egg production). Otherwise, most evidence has come by inference, based on body mass changes (Hatch 1990a,b, Warham 1990), and evidence of energetic limitations on reproductive performance later in the breeding season (Pinaud \& Weimerskirch 2002).

We studied the functional significance of the prelaying exodus in the northern fulmar Fulmarus glacialis. This is the only petrel with a northern, circumpolar distribution, and is a species for which information on nutrition and energetics was limited (Bryant \& Furness 1995, Furness \& Bryant 1996), and absent for Arctic colonies (Hatch \& Nettleship 1998). Both sexes of fulmars leave the colony, but the exodus by males is shorter than that by females (Mallory \& Forbes 2007). Females usually lay an egg within $1 \mathrm{~d}$ of their return, then depart while males begin the first incubation shift, which may last 2 wk (Hatch 1990b). Although most of the North Atlantic fulmar population breeds in the Boreal or Low Arctic oceanographic zone (Hatch \& Nettleship 1998), our study site was at a remote colony in the High Arctic zone (Salomonsen 1965), where cold temperatures, snow-covered breeding ledges and extensive sea ice meant that pairs had only a brief period between arrival at the colony and departure for the pre-laying exodus in which to pair bond, prepare their nest and copulate (Mallory \& Forbes 2007). We examined body composition of breeding northern fulmars collected just before departure and immediately upon return to detect potential links between the prelaying exodus and the pair's energetic needs. If female fulmars must leave to gather nutrients for egg production (i.e. income breeding), we predicted that preexodus females would lack sufficient endogenous reserves to produce an egg and still fly to their feeding grounds. Consequently, on their return from the exodus, we expected females to be in similar body condition as they were prior to undertaking the exodus, having used most of their acquired fat and protein reserves to form their egg. If male fulmars depart on the exodus to store energetic reserves for incubation, we predicted that pre-exodus males would lack sufficient fat to complete incubation for the first shift. Therefore, we expected male fulmars to have large fat reserves on their return from the exodus. Finally, we evaluated the duration of the fulmar exodus and the corresponding nutrient dynamics of the birds during this period as they related to the annual phenology of sea-ice cover and marine productivity in the Arctic. 


\section{MATERIALS AND METHODS}

Study area and marine environment. Research was conducted at the Cape Vera northern fulmar colony $\left(76^{\circ} 15^{\prime} \mathrm{N}, 89^{\circ} 15^{\prime} \mathrm{W}\right)$, northern Devon Island, Canada, in 4 field seasons: 8 May to 15 June, 1983; 26 May to 22 August, 2003; 14 May to 9 August 2004; and 20 April to 10 August 2005. Nearby Jones Sound remains icecovered from October through July of the following year, although there is open water immediately beside the colony in the Hell Gate-Cardigan Strait polynya (Mallory \& Fontaine 2004). The colony supports about 11000 pairs of fulmars.

The distribution of sea ice at the time of the fulmar exodus was determined from satellite imagery (http:// ice-glaces.ec.gc.ca), and is reproduced in Fig. 1. Although we did not track movements of fulmars during their exodus, birds equipped with satellite transmitters were followed starting on 12 July 2004 and 12 June 2005 (approximately $1 \mathrm{wk}$ after the completion of the pre-laying exodus). Mallory et al. (2008) describe the methods for this work in detail, but here (Fig. 1, circles) we show some of the main feeding areas during incubation as they related to the location of the colony and sea-ice extent.

Collections. Breeding schedules of northern fulmars at Cape Vera are highly synchronized within and across years, with the colony almost completely deserted between 20 to 30 May annually, and with colony numbers rapidly building from 1 June through mean egglaying (6 June; Mallory \& Forbes 2007). Fulmars were collected just before their departure for the exodus (15 to 18 May, before egg formation and thus considered pre-exodus), and immediately upon their return (5 to 11 June; considered post-exodus). Fulmar carcasses have been used for a variety of studies, including parasites (Mallory et al. 2006a, 2007), morphometrics (Mallory \& Forbes 2005), diet and contaminants (Mallory et al. 2006b). In 1983, 44 fulmars were collected with shotguns near the breeding cliffs (males: 11 preexodus, 16 post-exodus; females: 11 pre-exodus, 6 postexodus). On the day of collection, birds were weighed $( \pm 10 \mathrm{~g})$, and esophageal contents and gonads were removed and stored. In 2003 ( $\mathrm{n}=6$; males: 4 post-

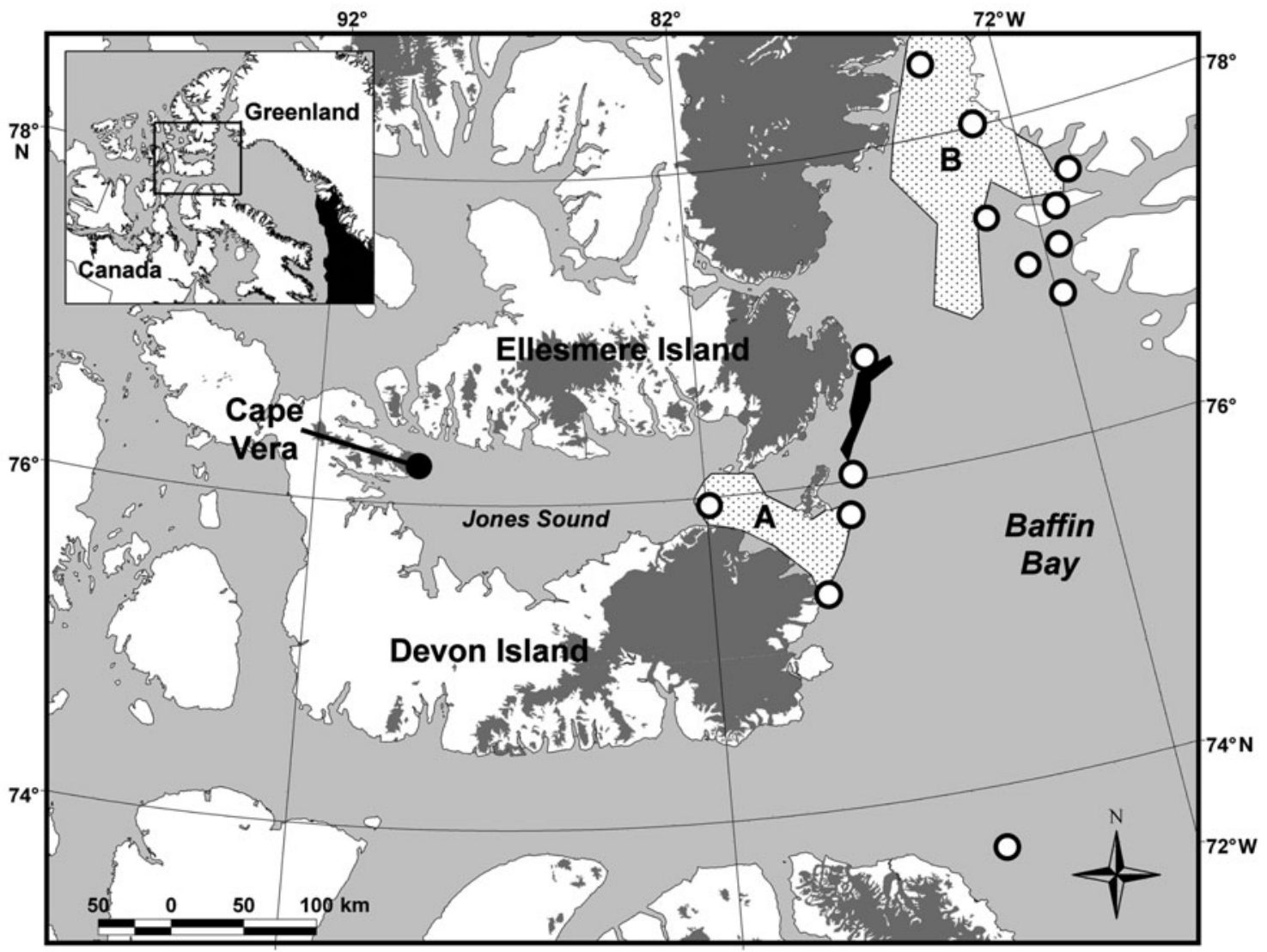

Fig. 1. Location of the Cape Vera study site on Devon Island, Nunavut, in the Canadian High Arctic, in relation to features of the marine environment in May 2005. Dark grey patches on land represent glaciers and ice caps. Solid black areas in the inset or east of Ellesmere Island in the main figure represent the only open water $(<10 \%$ ice cover) on 15 May. Areas A (mouth of Jones Sound) and B (North Water Polynya) had some open water ( 70\% ice-covered), and otherwise all marine areas (light grey) were ice-covered. o: locations where fulmars were foraging in June and July, as determined by satellite telemetry (Mallory et al. 2008) 
exodus, females: 2 post-exodus), birds were shot near the breeding cliffs, while in 2004 ( $\mathrm{n}=17$; males: 5 preexodus, 9 post-exodus; females: 3 pre-exodus) and 2005 ( $\mathrm{n}=11$; all post-exodus females), birds were captured on their nest site with noose poles and were immediately decapitated. All post-exodus female weights excluded mass of eggs. Fresh eggs $(n=7)$ were collected in nests where pairs were captured, while other eggs ( $n=17$ ) were collected in the first $10 \mathrm{~d}$ of incubation as part of other studies. Fulmars were weighed $( \pm 10 \mathrm{~g})$, and then they were frozen in air-tight bags and transported to the laboratory.

Nutrient analyses. Fulmars were thawed and morphometrics recorded (head length and keel length for all birds, as well as wing cord, tarsus length, culmen length and skull width for birds collected in 2003 to 2005, all in millimeters). All feathers were plucked, except the remiges, which were cut with scissors where they emerged from the skin, and the plucked bird was reweighed (plucked body mass, g). The leg and breast muscle from the left side of the body (Alisauskas \& Ankney 1985), liver, gizzard, and large and small intestines were removed, and weighed $( \pm 0.1 \mathrm{~g})$ or measured $( \pm 0.5 \mathrm{~cm})$. Intestinal contents were removed and stored. In 1983, the ovaries and oviducts of post-exodus females were inspected, and birds were considered as breeders if they had a post-ovulatory follicle and/or an oviducal egg. This approach was repeated in 2003 and 2004, while, in 2005, both postexodus males and females were collected on the nest on the day of laying. Thus, breeding status for postexodus females could be confidently surmised, as could that for most post-exodus males. We assumed that pre-exodus birds collected on nest sites or close to the cliffs were principally breeders ( $\geq 74 \%$ of birds at apparently occupied sites laid an egg; Mallory unpubl. data). Only birds that were presumed to be breeders were included in subsequent analyses.

For nutrient analyses, the liver, and leg and breast muscles were dried to constant mass at between 80 and $95^{\circ} \mathrm{C}$ (Keer et al. 1982). The intestine and the remainder of the carcass (excluding the half breast, 1 leg, liver, feathers and gonads/oviduct) were weighed (corrected mass, g), homogenized in a food grinder and oven-dried at between 80 and $95^{\circ} \mathrm{C}$ to constant dry mass. The dried liver, dried breast and leg muscles, and the dried carcass homogenate were ground separately with a portable coffee grinder. Lipid (hereafter fat) was extracted from an 8 to $10 \mathrm{~g}$ subsample of each of the ground body parts, using petroleum ether in a modified Soxhlet apparatus for $8 \mathrm{~h}$ (Dobush et al. 1985). The mass of the resultant lean dry sample was subtracted from the dry mass of the original sample, to obtain the mass of fat in the sample. A subsample of the lean dry residue from each extracted homogenate was placed in a preweighed crucible, and heated in a furnace at $550^{\circ} \mathrm{C}$ for $6 \mathrm{~h}$ (note that this was done only for females in 1983 samples, but for all birds in the other years). The remaining ash was weighed and divided by the mass of the lean dry sample to obtain the percentage of ash in each sample. Total fat in each body part (carcass, liver, breast, leg) was determined by multiplying the dried mass of the body part by the proportion of fat in the subsample of homogenate. Total ash in each body part was similarly determined by multiplying the proportion of ash in the subsample by the lean dry mass of the body part. Ash-free lean dry mass (a measure of protein content) was calculated as the dry mass of the body part minus total fat and ash.

The nutrient composition of eggs was determined by following similar protocols as outlined in Alisauskas \& Ankney (1985), except that yolk, albumen and membranes were kept together as 1 tissue for analysis. Eggs were boiled, and the shell was separated and ovendried for weighing $( \pm 0.01 \mathrm{~g})$. Egg albumen, yolk and shell membranes were dried to constant mass, and lipid and lean dry mass were determined as above for somatic tissues. Energy content of eggs was estimated by assuming $39.4 \mathrm{~kJ} \mathrm{~g}^{-1}$ in fat and $17.8 \mathrm{~kJ} \mathrm{~g}^{-1}$ in protein (Nagy 1983, Groscolas et al. 1991).

Estimating energy needs. The energy required to complete the first incubation shift plus a day to fly from the colony to a feeding site was estimated. Gabrielsen et al. (1988) and Bryant \& Furness (1995) reported a basal metabolic rate (BMR) for northern fulmars of 312 to $300 \mathrm{~kJ} \mathrm{~d}^{-1}$ and a field metabolic rate (FMR) averaging $1444 \mathrm{~kJ} \mathrm{~d}^{-1}$ (Furness \& Bryant 1996). The daily cost of incubation for male fulmars was estimated by deriving an equation from the relationship between incubation metabolic rate (IMR) and BMR presented for 14 petrels in Grant (1984), as follows:

$$
\begin{gathered}
\mathrm{IMR}=14.04+1.21(\mathrm{BMR}) \\
\left(\mathrm{r}_{14}=0.997, \mathrm{p}<0.001\right)
\end{gathered}
$$

Thus, for fulmars, the IMR is predicted to be between 392 and $414 \mathrm{~kJ} \mathrm{~d}^{-1}$, so we used $400 \mathrm{~kJ} \mathrm{~d}^{-1}$ as our estimate.

We compared the lipid, protein, mineral and water fractions of eggs to female endogenous reserves before the exodus, and assumed $100 \%$ conversion efficiency of endogenous stores to materials deposited in the egg for energetic estimates, acknowledging that this may be liberal (see Krementz \& Ankney 1986).

Statistical analyses. Head length $( \pm 0.1 \mathrm{~mm})$ and keel length $( \pm 0.1 \mathrm{~mm})$ were measured for all fulmars across years, and thus we created an index of body size using the first factor (PC1) from a principal component analysis on these measurements. PC1 explained 61.1 and $65.9 \%$ of body size variation in males and females, respectively. Body mass was positively correlated with 
$\mathrm{PC} 1$ in males $\left(\mathrm{mass}=20.2[\mathrm{PC} 1]+789.1, \mathrm{r}^{2}=0.14, \mathrm{df}=\right.$ $1,35, \mathrm{p}=0.02$ ), and was positively but not significantly correlated with PC1 in females (mass $=15.1[\mathrm{PC} 1]+$ 634.1, $\mathrm{r}^{2}=0.10, \mathrm{df}=1,25, \mathrm{p}=0.12$ ).

Depending on the distribution of data, $t$-tests, MannWhitney $U$-tests, coefficient of variation (CV), Pearson rank correlations, or stepwise general linear modelling were used to analyse data within sexes, and before and after the exodus (Systat Software, v. 2002). Collections were targeted to minimize the number of birds killed and to take advantage of carcasses used in other studies (see 'Materials and methods-Collections'). For this reason, there was a bias in sampling between breeding stage and year (e.g. in 2005, post-exodus females but no pre-exodus females were collected). During preliminary analyses, there was a significant stage $\times$ year interaction explaining variation in certain nutrients (notably lean dry mass), which was interpreted as the effect of sampling bias among years due to small samples within years. However, we were confident that any effects of annual variation on body composition were small for 3 reasons. First, fulmar breeding chronology at the Cape Vera colony is highly synchronized across years, presumably because sea-ice features, which dictate marine environmental conditions and food supplies, are driven by a recurrent polynya that is stable across years at this colony (Mallory \& Forbes 2007). Second, in 6 of 6 analyses on females that compared nutrient levels at the same stage among years, no significant differences were found (Mann-Whitney or Kruskal-Wallis tests, all p > 0.2). The same was true for males in 5 of 6 comparisons ( $p>0.1$ ), but, in 1983, post-exodus males had lower fat levels than postexodus males in $2004(\mathrm{p}=0.01)$. Nonetheless, the patterns of changes in body composition were similar in each year, although sample sizes were small. Thus, data were pooled across years for analyses, but we discuss the possible implications of the significant result for males below.

To evaluate whether male and female fulmars differed in body composition before and after the exodus, we first conducted a single MANOVA on independent body components (i.e. those which were not subcomponents of each other; body fat, water, lean dry mass, liver dry mass, liver fat), using sex and exodus as independent treatments. Significant multivariate main effects were then followed by univariate, 2-way, stepwise general linear models (GLMs) in analyses, where structural size (PC1) was a significant covariate, or t-tests (1-tailed, unequal variances) if PC1 was not significant. By preceding the GLMs with the MANOVA, an overall $\alpha$ (set at 0.1 to reduce Type II error rates due to small sample sizes) was maintained. We did not apply sequential Bonferroni corrections to p-values, as our results came from planned comparisons, and they satisfied reasonable and logical expectations (Moran 2003). Means $( \pm$ SE) are presented unless otherwise noted.

\section{RESULTS}

\section{Marine environment during the exodus}

On 15 May 2005 (approximately the start of the prelaying exodus of Fulmarus glacialis at Cape Vera), an area of partially open water (polynya; $70 \%$ ice-covered) extending approximately $3000 \mathrm{~km}^{2}$ was situated $200 \mathrm{~km}$ east of the breeding colony (Fig. 1), and $180 \mathrm{~km}$ farther northeast lay the southern boundary of the North Water Polynya ( 10 $000 \mathrm{~km}^{2}, 70 \%$ ice-covered). A small polynya $\left(\sim 750 \mathrm{~km}^{2},<10 \%\right.$ ice-covered) was located between the 2 larger polynyas, and otherwise the nearest region of open water lay $>1000 \mathrm{~km}$ southeast of the colony (Fig. 1). This pattern was similar in 2004, except that the North Water Polynya was larger, extended $100 \mathrm{~km}$ farther south, and was mostly open water by 15 May. In 2003, the North Water Polynya occupied a similar extent on 15 May as in 2005, but was $80 \%$ ice-covered, and there was no partially open water near the mouth of Jones Sound (i.e. fulmars had to travel $\geq 350 \mathrm{~km}$ to reach partially open water). Conditions in 1983 were similar to those in 2005. By the end of the exodus (ca. 1 June), the polynyas consistently had a higher proportion of open water.

Satellite tracking in 2004 and 2005 suggested that during incubation recesses, fulmars travelled to marine areas that were polynyas at the time of the pre-laying exodus (Fig. 1).

\section{Differences in body composition pre- and post-exodus}

Body mass and composition of both male and female fulmars differed before and after their breeding exodus (Table 1). The index of structural body size (PC1) was significantly correlated to total body mass in male fulmars (see 'Materials and methods-Statistical analyses'). However, PC1 was positively, but not significantly, correlated with the amount of body water, fat, or lean dry weight (LDW), either before or after the exodus in either sex (all $\mathrm{r}<0.4$, all $\mathrm{p}>0.13$ ), except for post-exodus males, where structurally larger males tended to have larger fat stores $(r=0.37, n=28, p=$ 0.07).

Among male fulmars, the structural size of fulmars collected before and after the exodus was similar (PC1 scores, $t_{38}=0.7, \mathrm{p}=0.4$; Table 1 ), but body mass was significantly heavier in post-exodus birds (Table 1). Structural size was also similar in pre- and post-exodus 


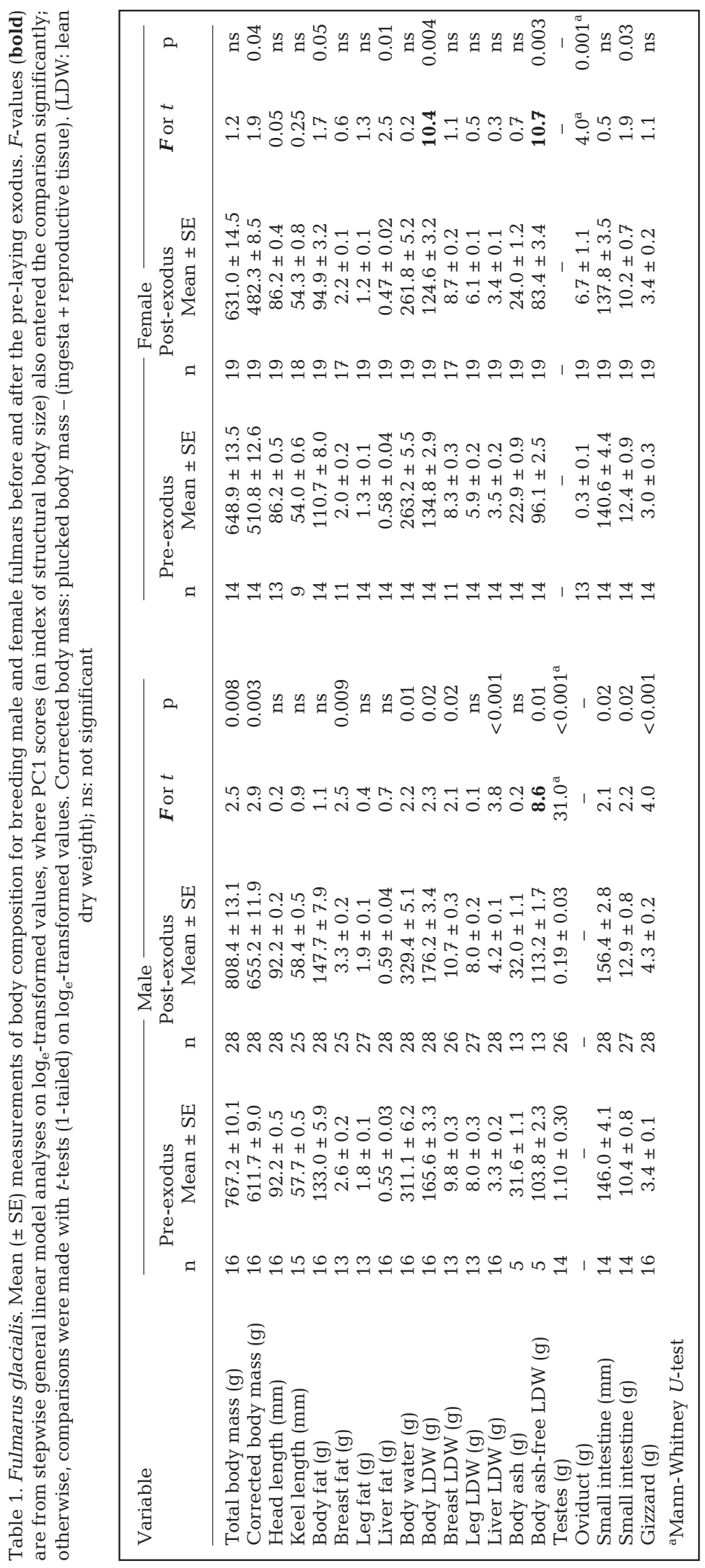

females (PC1 scores, $t_{25}=0.3, \mathrm{p}=0.8$ ), but breeding females captured shortly after their return from the exodus weighed less than females captured before the exodus (Table 1).

Wilks' lambda test criterion indicated that fulmar body composition was influenced by sex $\left(F_{4,71}=31.0, \mathrm{p}<0.001\right)$ and by the exodus $\left(F_{4,71}\right.$ $=2.7, \mathrm{p}=0.04$; interaction effects, $\mathrm{p}>0.25)$, so we used univariate comparisons to evaluate where this variation occurred (Table 1).

Post-exodus male fulmars were heavier than pre-exodus males because they had larger stores of fat $(11 \%)$, lean dry mass $(6 \%)$ and water (6\%; Fig. 2). After correcting for ash content in a subset of 18 males, ash-free lean dry mass was significantly larger $(9 \%)$ in postexodus males. As well, both breast fat and breast lean dry mass were heavier in postexodus males (Table 1). In male fulmars, body fat accounted for 17 to $18 \%$ of total body mass, but amounts of body fat in our sample of postexodus males were more variable (CV: $29 \%$ ) than in pre-exodus males (18\%).

A different pattern was evident for female fulmars, because they lost mass during the exodus. This was attributable, in part, to a $14 \%$ decline in body fat and an $8 \%$ decline in lean dry mass (after accounting for body size; Table 1, Fig. 2). Unlike males, however, there was no difference in body water for pre- and post-exodus females. Also, counter to the pattern observed in males, amounts of body fat in post-exodus females were less variable (CV: $15 \%)$ than in pre-exodus females $(27 \%)$, but accounted for a similar proportion of total body mass (15 to $17 \%$ ).

\section{Changes in organs}

Reproductive organ mass in both sexes changed during the exodus (Table 1). Male fulmars experienced a 5.7 -fold decrease in the mass of their testes, whereas females underwent a 22-fold increase in the mass of their oviduct, with oviduct mass changing from 0.05 to $1.0 \%$ of total body mass. Pre- and post-exodus female fulmars had similar intestine length and gizzard mass, but the small intestines were $18 \%$ lighter in post-exodus females. The small intestines of post-exodus males were $7 \%$ longer and $24 \%$ heavier, and gizzards were $26 \%$ heavier, compared to pre-exodus males (Table 1). Post-exodus males also had larger livers than pre-exodus males, notably composed 

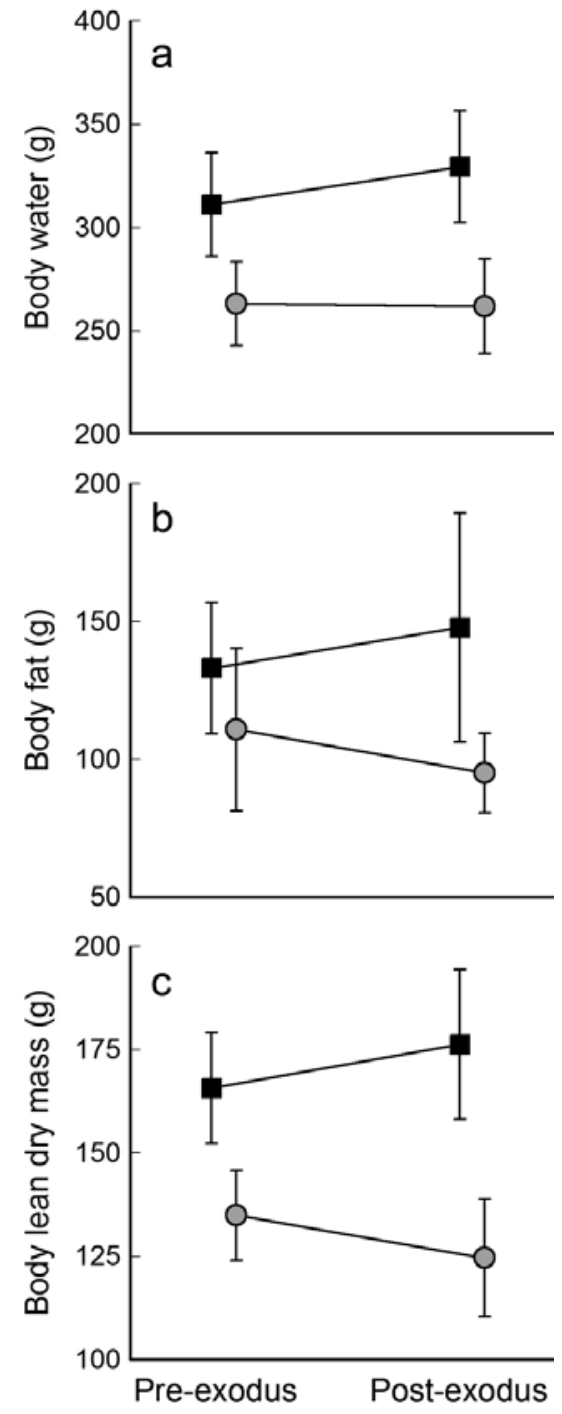

Fig. 2. Fulmarus glacialis. Mean $( \pm \mathrm{SD})(\mathrm{a})$ total body water, (b) body fat and (c) lean dry mass (protein + ash) in male (घ) and female (O) fulmars at Cape Vera, pre- and post-exodus

of $27 \%$ more lean dry mass. Post-exodus female livers had $19 \%$ less fat than pre-exodus females, but lean dry mass was similar.

\section{Energy needs}

Male fulmars take the first incubation shift immediately after the female lays the egg, and this shift averages $10.3 \mathrm{~d}$ at Cape Vera (Mallory 2008). At an IMR of about $400 \mathrm{~kJ} \mathrm{~d}^{-1}$, the average first incubation shift should require $4120 \mathrm{~kJ}$, and would total $5564 \mathrm{~kJ}$ including the average costs of flying $1 \mathrm{~d}$ from the colony to the feeding grounds $(1444 \mathrm{~kJ})$. This represents the energy content of $141 \mathrm{~g}$ of fat. The average male fulmar at Cape Vera had $148 \mathrm{~g}$ of fat stored post-
Table 2. Fulmarus glacialis. Composition (g) and energy content $(\mathrm{kJ})$ of northern fulmar eggs $(\mathrm{n}=24)$ collected from 2003 to 2005. The mass values in parentheses represent calculations for only the 7 fresh eggs

\begin{tabular}{|lcc|}
\hline Variable & Mean & SE \\
\hline Egg mass $(\mathrm{g})$ & $91.20(96.17)$ & $2.28(2.36)$ \\
Total protein $(\mathrm{g})$ & 12.04 & 0.36 \\
Total fat $(\mathrm{g})$ & 8.13 & 0.26 \\
Total mineral $(\mathrm{g})$ & 6.78 & 0.17 \\
Energy content $(\mathrm{kJ})$ & 534.6 & 15.5 \\
\hline
\end{tabular}

exodus (5831 kJ), an amount capable of supporting $11 \mathrm{~d}$ of incubation plus a day of flight to the feeding grounds (not including the energy also available from using stored protein).

Fresh eggs had higher mean water content (70.0 \pm $1.5 \mathrm{~g})$ than partly incubated eggs $\left(61.6 \pm 2.1 ; t_{20}=3.2\right.$, $\mathrm{p}=0.004)$, but fat, mineral and protein content were all similar ( $t$-tests, all $\mathrm{p}>0.38$ ), and thus values for all 24 eggs are presented in Table 2. Mean energy content of fresh eggs was $5.9 \pm 0.1 \mathrm{~kJ} \mathrm{~g}^{-1}(535 \mathrm{~kJ})$, and an average, fresh egg represented $14.8 \%$ of the body mass of pre-exodus females. Post-exodus females that laid an egg had about $16 \mathrm{~g}$ less body fat than pre-exodus females, representing twice as much fat as was deposited in the egg (Table 2). Similarly, after the exodus, females had $12.7 \mathrm{~g}$ less protein in their bodies, although some of this protein could have been mobilized for oviduct growth. Protein comprised 22 to $23 \%$ of breast and leg tissue wet mass, respectively, and thus $6.7 \mathrm{~g}$ of oviduct probably represents $1.5 \mathrm{~g}$ of protein (we did not analyse oviduct composition directly). Hence, even accounting for use of body protein for oviduct growth, the remaining amount of protein lost by females during the exodus (11.2 g) was roughly equivalent to the amount of protein in the egg $(12.0 \mathrm{~g})$. Eggs required $6.8 \mathrm{~g}$ of mineral to form the shell and $70 \mathrm{~g}$ of water for egg contents, representing $30 \%$ of the mineral (body ash) content and $27 \%$ of the body water of pre-exodus females, respectively. Post-exodus females had similar amounts of ash and water as preexodus females (Table 1).

\section{DISCUSSION}

\section{Ice, and fulmar movements during the exodus}

Northern fulmars Fulmarus glacialis nesting at Cape Vera encounter some annually predictable features in the marine environment surrounding their colony early in their breeding season. For example, by the start of the pre-laying exodus, they must fly a minimum of $200 \mathrm{~km}$ to reach the nearest partially open water, 
although in some years (e.g. 2004) this may be much farther. The North Water Polynya is partly open each year by mid-May and appears to be an important feeding area for these fulmars during incubation and chickrearing (Fig. 1), presumably due to its proximity to the colony and high productivity (Karnovsky \& Hunt 2002, Odate et al. 2002, Mallory \& Fontaine 2004). However, regional surveys suggest that few fulmars forage in this polynya during the exodus (McLaren 1982) and, instead, probably move $>1000 \mathrm{~km}$ southeast to the open waters along the west coast of Greenland before returning to their colonies to lay eggs. This suggests that during the pre-laying exodus, fulmars are unlikely to acquire sufficient marine food supplies near their colony, either due to the unpredictability of suitable open water foraging areas, or the relatively low marine production and availability of larger prey early in the season (Raymont 1976, Welch et al. 1992, Karnovsky et al. 2008). Predictable feeding sites are located $>1000 \mathrm{~km}$ away.

Why do fulmars breed at Cape Vera under such marine conditions? The benefit to fulmars breeding at this or other High Arctic sites may be that food resource acquisition (a key factor determining seabird reproductive success; Frederiksen et al. 2007) is comparatively easy during the summer pulse of abundant marine food resources in the Arctic (Welch et al. 1992), compared to fulmars nesting in the Boreal oceanographic zone. The summer coincides with the chickrearing stage, when breeding marine birds face their greatest energetic challenges (Ricklefs 1983, Whittow 2002). However, finding enough food during the prelaying exodus is also critical for fulmar reproduction, as they are clearly income breeders (see 'DiscussionFemale energetics'). To withstand the challenges imposed by extensive ice cover (i.e. distant and/or scarce food resources), High Arctic fulmars exhibit behavioral adjustments to their breeding schedule compared to conspecifics breeding at more southern colonies. These adaptations include a short period at the colony prior to the exodus and a pre-laying exodus 43 to $149 \%$ longer than at northern fulmar colonies in the southern part of their range (Mallory \& Forbes 2007). During the exodus, both male and female fulmars undergo substantial changes in body tissues, the size of which appear matched to their sex-specific requirements of egg-laying and incubation at this site.

\section{Body changes during the exodus}

Body mass, egg composition and water content of breeding northern fulmars at the Cape Vera colony were similar to values previously reported for fulmars or other petrels (Warham 1983, 1990, Hatch \& Nettle- ship 1998). In particular, fulmars exhibited high adiposity $(\sim 22 \%)$, similar to great-winged petrels Pterodroma macroptera (Groscolas et al. 1991) and higher than some long-term fasting penguins (Cherel et al. 1993). However, we found that body mass and nutrient levels of breeding fulmars changed during the prelaying exodus from the colony in late May, and that changes were in opposite directions for males and females, although both indicate income breeding. Body mass of male fulmars increased, because of protein, fat (notably breast fat) and water accumulation, whereas females lost body mass, particularly protein and fat. In an earlier study in Alaska, Hatch (1990a) showed that body mass of male fulmars also increased from pre-laying to laying, but by $14 \%$, whereas increases at Cape Vera were only $5 \%$. As well, Alaskan female fulmar body mass appeared to increase marginally (1\%; Fig. 8 in Hatch 1990a), while at Cape Vera, female mass declined by $3 \%$. While these studies confirm that fulmars have similar, sex-specific changes in body mass (and likely composition) during the exodus at each colony, the magnitude of the differences suggests colony-specific adaptations in nutrient dynamics to accommodate reproduction in response to the type or availability of prey within the foraging range of each colony.

\section{Female energetics}

Based on the differences in females before and after the exodus, and the composition of fulmar eggs, preexodus females had similar levels of endogenous fat and protein as was required to form an egg (excluding costs of biosynthesis; Grau 1984), as we predicted. In fact, during the exodus, female fat reserves declined by twice the amount of fat that was deposited in an egg, while declines in protein reserves were approximately equivalent to the protein found in an egg. However, egg requirements for water and minerals represented more than one-quarter of these total constituents in pre-exodus females, which presumably would have placed a severe strain on the female to liberate for egg synthesis, because female birds can only mobilize $\leq 15 \%$ of their skeletal calcium for egg production (Brenninkmeijer et al. 1997). This suggests that the principal function of the exodus is to allow female fulmars to acquire enough minerals to form the eggshell, as well as providing water for albumen production.

The changes we observed in nutrients of breeding female fulmars over the exodus are most consistent with a model of 'mineral limitation'. We hypothesize that female fulmars use some of their endogenous fat reserves (i.e. pre-exodus stores) to meet the require- 
ments of egg (yolk) synthesis, as well as fueling some of their existence energy and physiological changes while foraging during the exodus (analogous to High Arctic shorebirds; Morrison \& Hobson 2004). In support of this hypothesis, we found that lipophilic contaminants in females that had laid an egg were lower than in non-breeding females and males (Mallory et al. 2006b), suggesting that females had shed some of their contaminants with lipids contributed to egg production. Given the decline in protein reserves, despite a month foraging away from the colony, we suggest that much of the protein required for egg synthesis also came from the female's reserves, as observed in several species of waterfowl (Alisauskas \& Ankney 1992) and in great black-backed gulls Larus marinus (Mawhinney et al. 1999). By using some endogenous reserves to fulfill fat and protein requirements for egg production, we speculate that females forage for more mineral-rich (i.e. calcium-rich) items during the exodus, as found in other pre-laying female birds (e.g. Boersma et al. 2004). For example, they may feed less on squid during the exodus, which are typically an important component of High Arctic fulmar diets (Mallory 2006), but are relatively poor sources of calcium (Clarke \& Prince 1980, Cherel \& Ridoux 1992, Lawson et al. 1998). Female digestive organs did not increase in size over the exodus, as would be expected if they were foraging more heavily than before the exodus to acquire fat and protein (Ankney 1977, Drobney 1984). If this hypothesis is correct, we predict that: (1) male and female resource acquisition and allocation should differ during the exodus, which might be detected in isotopic studies, and (2) that females probably switch resource acquisition strategies immediately after the exodus to quickly recoup fat and protein stores.

Why would female reserves decline if the bird was away for 1 mo to feed? Fulmar eggs require $23 \mathrm{~d}$ to form (Mallory \& Forbes 2007), so the daily costs of egg synthesis would be relatively low. Nonetheless, during the exodus, fulmars in the High Arctic would be foraging at a time when marine productivity and food resources would be low but increasing, due to extensive ice-coverage and low sea-surface temperatures (Welch et al. 1992, Odate et al. 2002). Moreover, at this time, fulmars may face high competition with conspecifics and other seabirds for marine prey concentrated at predictable, productive sites such as ice edges (Hunt 1991). If females do forage specifically for mineral-rich prey during the exodus, then locating sufficient prey may be difficult early in the breeding season for fulmars at this latitude, which may explain why fulmars in the High Arctic have a markedly longer exodus than fulmars at lower latitudes (Mallory \& Forbes 2007), and why they lose more reserves than required strictly for egg formation (the present paper).

\section{Male energetics}

Our data support the hypothesis that males undertake the exodus to acquire nutrients for incubation. Pre-exodus males had $133 \mathrm{~g}$ of fat stores, which were sufficient to fuel the average first incubation shift and a flight to the feeding grounds if that shift started when the exodus started. However, if the female departs to gather nutrients for egg production (previous subsection) and the male was to remain at the nest site for $28 \mathrm{~d}$ (the average duration of the female exodus; Mallory \& Forbes 2007), then the male would require the equivalent of $282 \mathrm{~g}$ of fat (11 $200 \mathrm{~kJ})$, at a resting metabolic rate of $400 \mathrm{~kJ} \mathrm{~d}^{-1}$ (assuming $\mathrm{RMR} \approx \mathrm{IMR}_{\text {; Grant }}$ 1984). Even if these values overestimate energetic use by $100 \%$, pre-exodus males would still have insufficient reserves to initiate incubation on the female's return, and thus males must also depart to acquire nutrients to enable them to initiate incubation once the female has laid her egg. Thus, the exodus by males may be a required response to the female's energetic requirements.

Post-exodus males had $148 \mathrm{~g}$ of endogenous fat as well as stored protein. With their high adiposity and reduced metabolic rates while fasting during incubation (e.g. Cherel et al. 1993), these stores could support $11 \mathrm{~d}$ of incubation, more than was required to fuel the average, first incubation shift at Cape Vera. We also found that post-exodus male fat stores were more variable than those in pre-exodus males, which may be attributable to: (1) incorporation of some non-breeding males in the sample (probably had smaller fat stores), (2) foraging differences among males (male quality and experience), or (3) variation in fat stores to meet different incubation schedules. Given the finding that fat levels were significantly lower in 1983 compared to 2004, post-exodus males (see 'Materials and methods') and that the 1983 males were shot near the cliffs while the 2004 males were taken from nests, we believe that the first option above fits our data, that is, some nonbreeding, post-exodus males were included in our 1983 sample. However, the result of this bias is that we have underestimated the amount of reserves acquired over the exodus, and thus our overall interpretation of patterns remains the same. There is also support for the third option, in that there is considerable variation among fulmar pairs in incubation scheduling (Hatch 1990c, Mallory 2008). Given that mate fidelity and breeding experience have a critical influence on fulmar reproductive success (Hatch \& Nettleship 1998), pair-specific patterns of incubation scheduling might be reflected in differences in endogenous reserve levels for incubation.

Males also increased the amount of water stored in skeletal muscle during the exodus. This was attribut- 
able in part to males increasing their levels of protein during the exodus, because protein and water levels generally change simultaneously in lean tissues (Groscolas et al. 1991). While catabolism of fat may be a source of metabolic water (Ricklefs et al. 1978), males may have been storing additional water, perhaps to meet challenges in maintaining water balance for a long, uninterrupted incubation shift ( 11 d) in an arid environment.

Hatch (1983) found that female fulmars had sperm storage glands, and he suggested that this could allow pairs to forage separately over pelagic waters during the exodus, because mating would already be completed. Our data support this hypothesis. Unlike postexodus female fulmars, whose digestive organs showed little difference from pre-exodus females (and appeared to lose mass), male fulmars collected after the exodus had significantly larger digestive organs and livers than pre-exodus males, which suggests that males increased foraging rates during the exodus (Ankney 1977, Drobney 1984). Male and female fulmars also depart and return at different times for their exodus (Hatch 1990b, Mallory \& Forbes 2007). Thus, differences in exodus scheduling, digestive organ changes, body composition changes and mass trajectories all suggest that female and male fulmars have different resource acquisition and allocation strategies during their pre-laying exodus, and these might include foraging in different regions or marine habitats. Interestingly, Grosbois \& Thompson (2005) found differences in the effects of winter climate on survival of male and female fulmars in the northern UK, and hypothesized that a contributing factor could be differences between the sexes in foraging energetics or foraging areas, as found for albatrosses (e.g. Shaffer et al. 2001). Our findings would be consistent with their hypothesis, in that resource acquisition strategies may differ between the sexes through much of the year.

\section{Tissue nutrient dynamics}

Fulmar reproductive organs changed predictably in size during the exodus. Copulation is frequent before the exodus, but there are no mating opportunities following this date (Hatch \& Nettleship 1998), so in males testes size should decline. In contrast, females fertilize eggs during the exodus at Cape Vera (28 d exodus, 23 d egg formation; Mallory \& Forbes 2007), using stored sperm (Hatch 1983), after which oviduct growth appears to be rapid.

Unlike geese, gulls and penguins (Ankney \& MacInnes 1978, Houston et al. 1983, Cherel et al. 1994b), where the pectoral muscle is the primary source of endogenous protein (Blem 1990), we found no change in either protein or fat content of female fulmar pectoral muscles during the exodus (although males stored reserves in the pectoral region). Fulmars (and other petrels) are highly reliant on efficient flight for foraging (Warham 1990, Furness \& Bryant 1996), so declines in the size, strength, or efficiency of the pectoral muscles may have a deleterious effect on feeding ability during the exodus. Thus, selection may have favored mobilization of nutrients for egg formation from other body tissues. However, it is unclear which tissues might serve as the source of protein for females. The decline in mass of the intestine $(2.2 \mathrm{~g})$ represented only $17 \%$ of the observed decline in body lean dry mass $(12.7 \mathrm{~g})$, and was only $0.5 \mathrm{~g}$ more than the amount of protein required for oviduct growth. We did not see changes in lean dry mass of any other specific tissues we examined (breast, leg, liver, gizzard; Table 1), and thus further investigation is required to determine protein dynamics for breeding female fulmars.

\section{Oceanographic zones and the implications for other colonies}

Nutrient dynamics for fulmars at Cape Vera represent the situation at the extreme northern limit of the breeding range for this species (Hatch \& Nettleship 1998), in the High Arctic oceanographic zone, where breeding phenology and marine food supplies are largely constrained by the timing and extent of annual marine ice cover. At more southern colonies in the Boreal and Low Arctic oceanographic zones, breeding is initiated earlier in the year, males and females undertake an exodus which may be 2 wk shorter and may be punctuated by brief returns to the colony (Hatch 1990a), and many fulmars have alternate food sources to prey upon (Hatch \& Nettleship 1998, Mallory 2006). Importantly, fish and fisheries offal, both presumably excellent sources of minerals, protein and fat, form a higher proportion of the diet in fulmars at more southern colonies (Mallory 2006). Thus, while mineral limitation may also explain the fulmar exodus at colonies further south, differences in breeding phenology and available food supplies apparently permit females to spend less time away from the colony, and may allow females to more quickly recover fat and protein used for egg production. As well, fulmars return from wintering grounds to High Arctic colonies with proportionally larger reserves than fulmars at Boreal or Low Arctic colonies to compensate for relatively low, marine production in the early season in the High Arctic (Mallory \& Forbes 2008). This might account for differences in mass trajectories between our study and those found by Hatch (1990a). 
Our data clearly are consistent with the hypothesis that insufficient endogenous reserves, particularly of minerals, are an important motivation for the prelaying exodus by High Arctic northern fulmars. Moreover, the size of nutrient reserves acquired during the exodus differed among the sexes, apparently in response to the behavioral and energetic constraints placed on fulmars by the ice-covered marine environment and consequent low and distant food supplies early in the breeding season. We propose that differences in quality and quantity of exogenous nutrient supplies in marine environments contribute to observed behavioral differences in the pre-laying exodus of fulmars, and we predict that substantial differences occur in nutrient dynamics during the exodus across the species' range.

\section{Constraints of sea ice in a warming climate}

Migratory marine wildlife breeding in the Arctic must adapt and respond to the seasonal pattern of ice cover, which affects access to their food resources. During years of abnormally extensive sea ice and delayed ice breakup, relatively less food is produced in ice-affected areas, and key feeding sites (ice edges and leads) form much later in the season. Some species, like black-legged kittiwakes Rissa tridactyla and thickbilled murres Uria lomvia, adjust the timing and effort of their breeding in response to annual ice conditions and available food supplies (Gaston et al. 2005). In contrast, High Arctic fulmars return to breed at the same time each year (Mallory \& Forbes 2007), but have adapted their storage and management of energetic reserves to exploit marine food supplies at predictable open water distant from their colony. Arctic sea ice is breaking up earlier in the year in response to a warming climate (ACIA 2005). Consequently, more open water available earlier in the season should lead to an earlier pulse of marine production and a greater availability of foraging areas, and thus may relax some of the energetic constraints imposed on northern fulmars and other seabirds breeding in the High Arctic.

Acknowledgements. We thank the many students and collaborators who made the Cape Vera project possible in 1983 and 2003 to 2005, especially J. Akearok, A. Dzubin, D. Edwards, A. Fontaine, K. O'Donovan, G. Prach and G. Wagner. Collections were in accordance with the Canadian Council on Animal Care guidelines, and were conducted under the following permits: research (NUN-SCI-03-02, WL000190, WL000714), animal care (2003PNR017, 2004PNR021，2005PNR021) and land use (59A/7-2-2). K. Wilcox and the Bird Studies Canada Avian Energetics Laboratory provided excellent analyses of carcass and egg composition. We thank 4 anonymous referees who provided insightful reviews of the manuscript. Financial and logistic support was provided by Environment Canada (NCD, NEI), Natural Resources Canada (PCSP), the Nunavut Wildlife Management Board, Indian and Northern Affairs Canada (NSTP) and Carleton University.

\section{LITERATURE CITED}

ACIA (2005) Arctic Climate Impact Assessment. Cambridge University Press, Cambridge

Aebischer NJ, Coulson JC, Colebrook JM (1990) Parallel long-term trends across four marine trophic levels and weather. Nature 347:753-755

Alisauskas RT, Ankney CD (1985) Nutrient reserves and the energetics of reproduction in American coots. Auk 102: 133-144

Alisauskas RT, Ankney CD (1992) The cost of egg laying and its relationship to nutrient reserves in waterfowl. In: Batt BDJ, Afton AD, Anderson MG, Ankney CD, Johnson DH, Kadlec JA, Krapu GL (eds) Ecology and management of breeding waterfowl. University of Minnesota Press, Minneapolis, p 30-62

Ankney CD (1977) Feeding and digestive organ size in breeding lesser snow geese. Auk 94:275-282

Ankney CD, MacInnes CD (1978) Nutrient reserves and reproductive performance in female lesser snow geese. Auk 95:459-471

Baldwin SP, Kendeigh SC (1938) Variations in the weight of birds. Auk 55:416-467

Blem CR (1990) Avian energy storage. Curr Ornithol 7:59-113

Boersma PD, Rebstock GA, Stokes DL (2004) Why penguin eggshells are thick. Auk 121:148-155

Boyd I, Wanless S, Camphuysen CJ (2006) Top predators in marine ecosystems. Their role in monitoring and management. Cambridge University Press, Cambridge

Brenninkmeijer A, Klassen M, Stienen EWM (1997) Sandwich terns Sterna sandvicensis feeding on shell fractions. Ibis 139:397-400

> Bryant DM, Furness RW (1995) Basal metabolic rates of North Atlantic seabirds. Ibis 137:219-226

Cairns DK (1987) Seabirds as indicators of marine food supplies. Biol Oceanogr 5:261-271

Cherel Y, Ridoux V (1992) Prey species and nutritive value of food fed during summer to king penguin Aptenodytes patagonica chicks at Possession Island, Crozet Archipelago. Ibis 134:118-127

Cherel Y, Charrassin JB, Handrich Y (1993) Comparison of body reserve buildup in prefasting chicks and adults of king penguins (Aptenodytes patagonicus). Physiol Zool 66:750-770

Cherel Y, Charrassin JB, Challet E (1994a) Energy and protein requirements for molt in the king penguin Aptenodytes patagonicus. Am J Physiol 266:1182-1188

Cherel Y, Gilles J, Handrich Y, Le Maho Y (1994b) Nutrient reserves dynamics and energetics during long-term fasting in the king penguin (Aptenodytes patagonicus). J Zool (Lond) 234:1-12

Clarke A, Prince PA (1980) Chemical composition and calorific value of food fed to mollymauk chicks Diomedea melanophris and D. chrysostoma at Bird Island, South Georgia. Ibis 122:488-494

> Dobush GR, Ankney CD, Krementz DG (1985) The effect of apparatus, extraction time, and solvent type on lipid extractions of snow geese. Can J Zool 63:1917-1920

Drent RH, Daan S (1980) The prudent parent: energetic adjustments in avian breeding. Ardea 68:225-252

Drobney RD (1984) Effect of diet on the visceral morphology 
of wood ducks. Auk 101:93-98

Frederiksen M, Edwards M, Richardson AJ, Halliday NC, Wanless S (2006) From plankton to top predators: bottomup control of a marine food web across four trophic levels. J Anim Ecol 75:1259-1268

Frederiksen M, Mavor R, Wanless S (2007) Seabirds as environmental indicators: the advantages of combining datasets. Mar Ecol Prog Ser 352:205-211

Furness RW, Bryant DM (1996) Effect of wind on field metabolic rates of breeding northern fulmars. Ecology 77 : 1181-1188

Gabrielsen GW, Mehlum F, Karlsen HE (1988) Thermoregulation in four species of arctic seabirds. J Comp Physiol B 157:703-708

Gaston AJ, Gilchrist HG, Mallory ML (2005) Variation in ice conditions has strong effects on the breeding of marine birds at Prince Leopold Island, Nunavut. Ecography 28: $331-344$

Grant GS (1984) Energy cost of incubation to the parent bird. In: Whittow GC, Rahn H (eds) Seabird energetics. Plenum Press, New York, p 59-72

Grau CR (1984) Egg formation. In: Whittow GC, Rahn H (eds) Seabird energetics. Plenum Press, New York, p 33-58

Griminger P (1986) Lipid metabolism. In: Sturkie PD (ed) Avian physiology. Springer Publishers, New York, p 345-358

Grosbois V, Thompson PM (2005) North Atlantic climate variation influences survival in adult fulmars. Oikos 109: 273-290

Groscolas R, Schreiber L, Morin F (1991) The use of titrated water to determine protein and lipid utilization in fasting birds: a validation study in incubating great-winged petrels, Pterodroma macroptera. Physiol Zool 64:1217-1233

Hatch SA (1983) Mechanism and ecological significance of sperm storage in the northern fulmar with reference to its occurrence in birds. Auk 100:593-600

> Hatch SA (1990a) Time allocation by northern fulmars Fulmarus glacialis during the breeding season. Ornis Scand 21:89-98

> Hatch SA (1990b) Incubation rhythm in the fulmar Fulmarus glacialis: annual variation and sex roles. Ibis 132:515-524

Hatch SA (1990c) Individual variation in behavior and breeding success of northern fulmars. Auk 107:750-755

Hatch SA, Nettleship DN (1998) Northern fulmar (Fulmarus glacialis). In: Poole A, Gill F (eds) The birds of North America, No. 361. The Birds of North America Inc., Philadelphia, PA

Houston DC, Jones PJ, Sibly RM (1983) The effect of female body condition on egg laying in lesser black-backed gulls Larus fuscus. J Zool 200:509-520

Hunt GL Jr (1991) Marine ecology of seabirds in polar oceans. Am Zool 31:131-142

Karnovsky NJ, Hunt GL Jr (2002) Estimation of carbon flux to dovekies (Alle alle) in the North Water. Deep-Sea Res 49:5117-5130

Karnovsky NJ, Hobson KA, Iverson S, Hunt GL Jr (2008) Seasonal changes in diets of seabirds in the North Water Polynya: a multiple-indicator approach. Mar Ecol Prog Ser 357:291-299

Kerr DC, Ankney CD, Millar JS (1982) The effect of drying temperature on extraction of petroleum ether soluble fats of small birds and mammals. Can J Zool 60:470-472

Krementz DG, Ankney CD (1986) Bioenergetics of egg production by female house sparrows. Auk 103:299-305

Lack D (1968) Ecological adaptations for breeding in birds. Methuen Press, London

¿awson JW, Magalhães AM, Miller EH (1998) Important prey species of marine vertebrate predators in the northwest
Atlantic: proximate composition and energy density. Mar Ecol Prog Ser 164:13-20

Mallory ML (2006) The northern fulmar (Fulmarus glacialis) in Arctic Canada: ecology, threats, and what it tells us about marine environmental conditions. Environ Rev 14: 187-216

Mallory ML (2008) Incubation scheduling by northern fulmars in the Canadian High Arctic. J Ornithol 149 (Online First) doi:10.1007/s10336-008-0332-8

Mallory ML, Fontaine AJ (2004) Key marine habitat sites for migratory birds in Nunavut and the Northwest Territories. Occ Pap 109, Canadian Wildlife Service, Ottawa

Mallory ML, Forbes MR (2005) Sex discrimination and measurement bias in northern fulmars (Fulmarus glacialis) from the Canadian Arctic. Ardea 93:25-36

Mallory ML, Forbes MR (2007) Does sea-ice constrain the breeding schedules of High Arctic northern fulmars? Condor 109:894-907

Mallory ML, Forbes MR (2008) Costly pre-laying behaviors and physiological expenditures by northern fulmars in the High Arctic. Ecoscience 15 (in press)

Mallory ML, Forbes MR, Galloway TD (2006a) Ectoparasites of northern fulmars Fulmarus glacialis (Procellariformes: Procellariidae) from the Canadian Arctic. Polar Biol 29:353-357

Mallory ML, Braune BM, Forbes MR (2006b) Breeding and contaminant concentrations in northern fulmars (Fulmarus glacialis L.) from the Canadian High Arctic. Chemosphere 64:1541-1544

Mallory ML, McLaughlin JD, Forbes MR (2007) Breeding status, contaminant burden and endoparasites of northern fulmars (Fulmarus glacialis) from the Canadian High Arctic. Ibis 149:338-344

Mallory ML, Akearok J, Edwards DB, O'Donovan K, Gilbert CD (2008) Autumn migration and wintering of northern fulmars (Fulmarus glacialis) from the Canadian high Arctic. Polar Biol 31:745-750

Marshall AJ, Serventy DL (1956) The breeding cycle of the short-tailed shearwater, Puffinus tenuirostris (Temminck), in relation to trans-equatorial migration and its environment. Proc Zool Soc Lond 127:489-510

Mawhinney K, Diamond AW, Kehoe FP (1999) The use of energy, fat, and protein reserves by breeding great blackbacked gulls. Can J Zool 77:1459-1464

McLaren PL (1982) Spring migration and habitat use by seabirds in eastern Lancaster Sound and western Baffin Bay. Arctic 35:88-111

- Meijer T, Drent R (1999) Re-examination of the capital and income dichotomy in breeding birds. Ibis 141:399-414

> Moran MD (2003) Arguments for rejecting the sequential Bonferroni in ecological studies. Oikos 100:403-405

Morrison RIG, Hobson KA (2004) Use of body stores in shorebirds after arrival on High-Arctic breeding grounds. Auk 121:333-344

Nagy KA (1983) The doubly labeled water $\left({ }^{3} \mathrm{HH}^{18} \mathrm{O}\right)$ method: a guide to its use. Publication No. 12-1417, University of California, Los Angeles

Odate T, Hirawake T, Sakae K, Klein B, LeBlanc B, Fukuchi M (2002) Temporal and spatial patterns in the surface-water biomass of phytoplankton in the North Water. Deep-Sea Res 49:4947-4958

> Pinaud D, Weimerskirch H (2002) Ultimate and proximate factors affecting the breeding performance of a marine top predator. Oikos 99:141-150

Raymont JEG (1976) Plankton and productivity in the oceans. Pergamon Press, Toronto

Ricklefs RE (1983) Some considerations on the reproductive 
energetics of pelagic seabirds. Stud Avian Biol 8:84-94

Ricklefs RE, Hahn DC, Montevecchi WA (1978) The relationship between egg size and chick size in the laughing gull and Japanese quail. Auk 95:135-144

Ricklefs RE, Roby DD, Williams JB (1986) Daily energy expenditure by adult Leach's storm-petrels during the nesting cycle. Physiol Zool 59:649-660

Salomonsen F (1965) The geographical variation of the fulmar (Fulmarus glacialis) and the zones of marine environment in the North Atlantic. Auk 82:327-355

Shaffer SA, Weimerskirch H, Costa DP (2001) Functional significance of sexual dimorphism in wandering albatrosses, Diomedea exulans. Funct Ecol 15:203-210

Stenseth NC, Ottersen G, Hurrell JW, Belgrano A (2004) Marine ecosystems and climate variation. Oxford Univer-

Editorial responsibility: Brent Stewart,

San Diego, CA, USA sity Press, Oxford

Stirling I (1997) The importance of polynyas, ice edges and leads to marine mammals and birds. J Mar Syst 10:9-21

> Warham J (1983) The composition of petrel eggs. Condor 85:194-199

Warham J (1990) The petrels - their ecology and breeding systems. Academic Press, London

Warham J (1996) The behavior, population biology and physiology of the petrels. Academic Press, London

Welch HE, Bergmann MA, Siferd TD, Martin KA and others (1992) Energy flow through the marine ecosystem of the Lancaster Sound region, Arctic Canada. Arctic 45:343-357

Whittow GC (2002) Seabird reproductive physiology and energetics. In: Schreiber EA, Burger J (eds) Biology of marine birds. CRC Press, New York, p 409-437

Submitted: April 28, 2008; Accepted: November 13, 2008 Proofs received from author(s): December 2, 2008 